\title{
U.S. DEPARTMENT OF ENERGY NEVADA OPERATIONS OFFICE ENVIRONMENTAL MONITORING PROGRAM SUMMARY DATA REPORT FIRST CALENDAR QUARTER 1997
}

OCTOBER 1997

Work Performed Under Contract No. DE-AC08-96NV11718
RFCEIVED

NOV 071997

USTI

Prepared for

Nevada Operations Office

U.S. Department of Energy

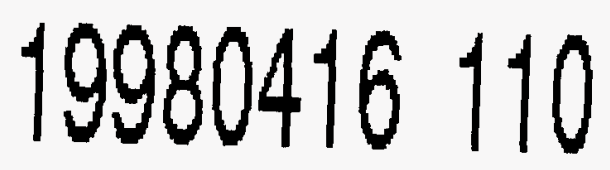

Prepared by

Bechtel Nevada

Post Office Box 98521

Las Vegas, Nevada 89193-8521 
This report has been reproduced directly from the best available copy.

Available to DOE and DOE contractors from the:

Office of Scientific and Technical Information

P.O. Box 62

Oak Ridge, Tennessee 37831

Prices available from (423) 576-8401

Available to public from the:

National Technical Information Service

U.S. Department of Commerce

5285 Port Royal Rd.

Springfield, VA 22161

Prices available from (703) $487-4650$ 


\section{DISCLAIMER}

This report was prepared as an account of work sponsored by an agency of the United States Government. Neither the United States Government nor any agency thereof, nor any of their employees, makes any warranty, express or implied, or assumes any legal liability or responsibility for the accuracy, completeness, or usefulness of any information, apparatus, product, or process disciosed, or represents that its use would not infringe privately owned rights. Reference herein to any specific commercial product, process, or service by trade name, trademark, manufacturer, or otherwise does not necessarily constitute or imply its endorsement, recommendation, or favoring by the United States Government or any agency thereof. The views and opinions of authors expressed herein do not necessarily state or reflect those of the United States Government or any agency thereof. 


\section{U.S. DEPARTMENT OF ENERGY NEVADA OPERATIONS OFFICE ENVIRONMENTAL MONITORING PROGRAM SUMMARY DATA REPORT FIRST CALENDAR QUARTER 1997}

Editors: Stuart C. Black, Orin L. Haworth, and Yvonne E. Townsend

October 1997

Work Performed Under

Contract DE-AC08-96NV11718

Prepared for

Nevada Operations Office

U.S. Department of Energy

DISTRIBUTON OF AHS DOCUMLNT IS UNLIMTTED

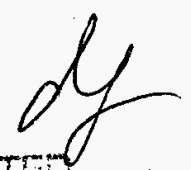

Prepared by

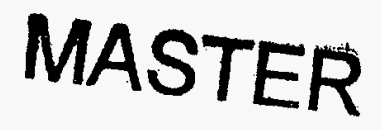

Bechtel Nevada

Post Office Box 98521

Las Vegas, Nevada 89193-8521 


\section{ACKNOWLEDGMENTS}

Frank R. Grossman compiled and verified radiological onsite data, and Orin Haworth provided the non-radiological data. R. R. Kinnison provided the statistical analyses necessary for this report. The production of this report would not have been possible without the dedication, expertise, and professionalism of these individuals. 


\section{TABLE OF CONTENTS}

Acknowledgments $\ldots \ldots \ldots \ldots \ldots \ldots \ldots \ldots \ldots \ldots \ldots \ldots \ldots \ldots \ldots \ldots \ldots \ldots$ iii

Table of Contents $\ldots \ldots \ldots \ldots \ldots \ldots \ldots \ldots \ldots \ldots \ldots \ldots \ldots \ldots \ldots$

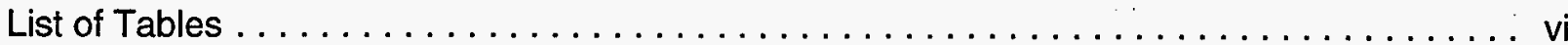

List of Figures $\ldots \ldots \ldots \ldots \ldots \ldots \ldots \ldots \ldots \ldots \ldots \ldots \ldots \ldots \ldots \ldots \ldots$

List of Acronyms $\ldots \ldots \ldots \ldots \ldots \ldots \ldots \ldots \ldots \ldots \ldots \ldots \ldots \ldots \ldots \ldots \ldots \ldots$

1.0 Radiological Environmental Surveillance $\ldots \ldots \ldots \ldots \ldots \ldots \ldots \ldots \ldots \ldots \ldots \ldots$

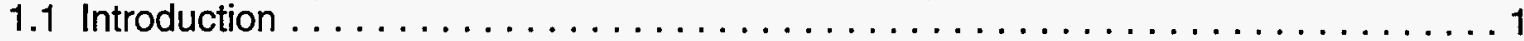

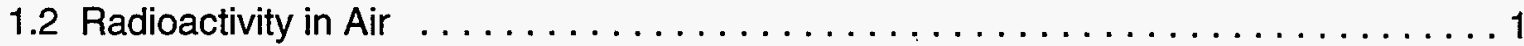

1.2.1 Air Particulate Sampling Results . . . . . . . . . . . . . . . . . 1

1.2.1.1 Gross Alpha/Beta and Gamma Spectral Analyses . . . . . . . . . . 5

1.2.1.2 Nellis Air Force Range Complex Samples . . . . . . . . . . . . . 5

1.2.1.3 Plutonium Analyses . . . . . . . . . . . . . . . . . . . . 5

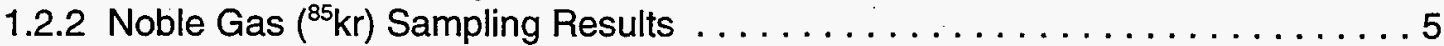

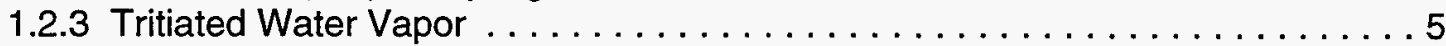

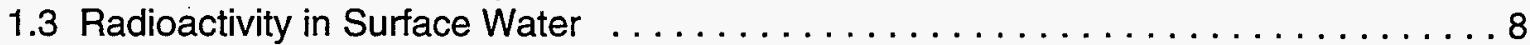

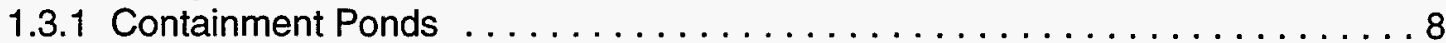

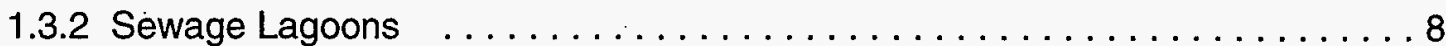

1.4 Radioactivity in Supply Well Water $\ldots \ldots \ldots \ldots \ldots \ldots \ldots \ldots \ldots \ldots \ldots$

1.4 .1 Gross Beta . . . . . . . . . . . . . . . . . . . . . . . 9

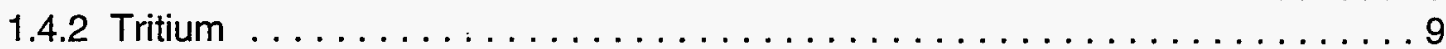

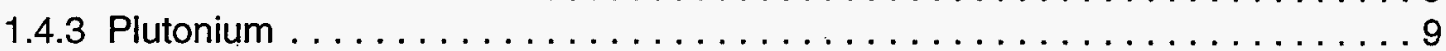

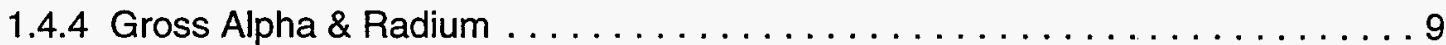

1.4 .5 Strontium . . . . . . . . . . . . . . . . . . . . . . . 10

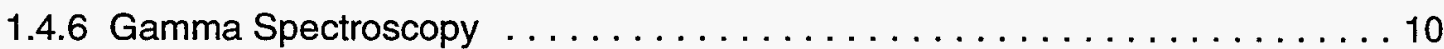



1.5 .1 Gross Beta . . . . . . . . . . . . . . . . . . . . . . . . . . . . 10

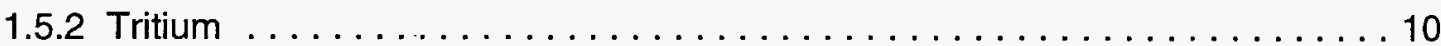

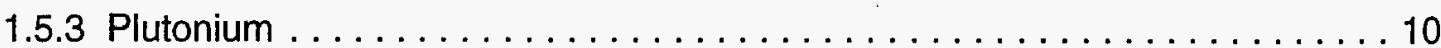

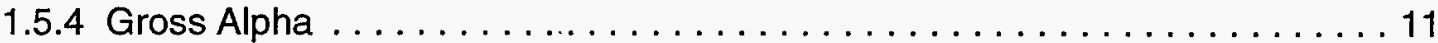

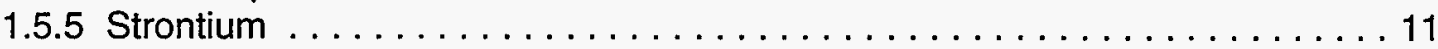

1.5.6 Gamma Spectroscopy . . . . . . . . . . . . . . . . . 11

2.0 Non-radiological Effluent Monitoring $\ldots \ldots \ldots \ldots \ldots \ldots \ldots \ldots \ldots \ldots \ldots \ldots \ldots \ldots$

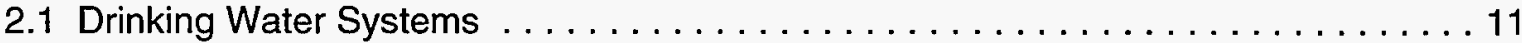

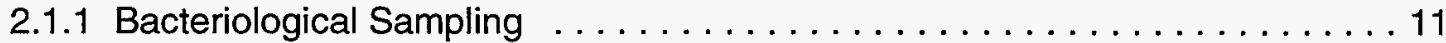

2.1 .2 Chemical Analysis . . . . . . . . . . . . . . . . . . . . . . 11

2.2 Sewage Lagoons . . . . . . . . . . . . . . . . . . . . . . 12

2.3 Non-hazardous Solid Waste Disposal $\ldots \ldots \ldots \ldots \ldots \ldots \ldots \ldots \ldots \ldots \ldots$

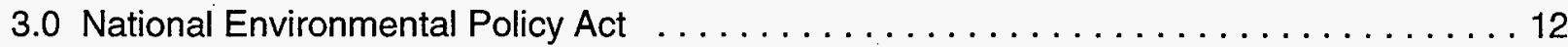

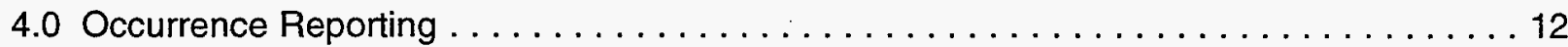

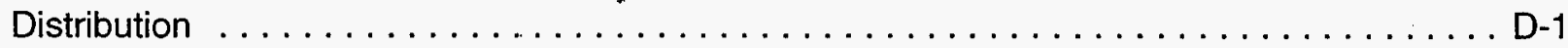




\section{LIST OF TABLES}

Page

Table 1.1 Network Collection and Analysis Data . . . . . . . . . . . . . . . . . . . . . . 14

Table 1.2 Derived Limits for Radionuclides in Air and Water . . . . . . . . . . . . . . . . 14

Table 1.3 Summary Data for Gross Alpha, Gross Beta, and ${ }^{7} \mathrm{Be}$ in Air - First Quarter,

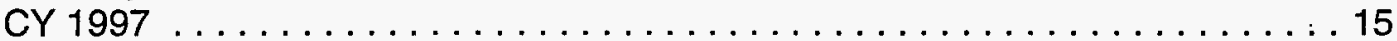

Table 1.4 Offsite Particulate and Onsite ${ }^{85} \mathrm{Kr}$ in Air Summary Data - First Quarter,

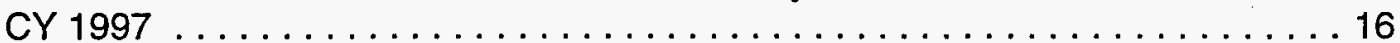

Table 1.5 Tritium in Atmospheric Moisture Summary Data - First Quarter, CY 1997. . . . . . 16

Table 1.6 Summary Data for Well and Surface Water Samples - First Quarter,

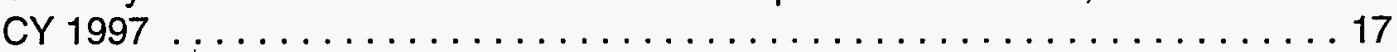

Table 1.7 Potable Water Sample Summary Results $(\mu \mathrm{Ci} / \mathrm{mL})$ - First Quarter, CY 1997 . . . 18

Table 1.8 Pond Water Depths in Infiltration Basins - First Quarter, CY 1997 . . . . . . . . . 18

Table 1.9 Influent Quality - First Quarter, CY $1997 \ldots \ldots \ldots \ldots \ldots \ldots \ldots$

Table 1.10 Organic Loading Rates - First Quarter, CY 1997 . . . . . . . . . . . . . . . . . 19

Table 1.11 Sample Results for Infiltration Basins that receive $30 \mathrm{~cm}$ or more of

Liquid - First Quarter, CY 1997 . . . . . . . . . . . . . . . . . . . . 20

Table 1.12 Quantity of Waste Disposed of in Landfills - First Quarter, CY 1997 . . . . . . . 20

Table 1.13 NEPA Documentation - First Quarter, CY $1997 \ldots \ldots \ldots \ldots \ldots \ldots \ldots$

Table 1.14 Environmental Occurrences at NTS Facilities - First Quarter, CY 1997 . . . . . 21

\section{LIST OF FIGURES}

Figure 1.1 Location of NTS Air Sampling Stations, $1997 \ldots \ldots \ldots \ldots \ldots \ldots \ldots \ldots \ldots$

Figure 1.2 Location of NTS Water Sampling Stations, $1997 \ldots \ldots \ldots \ldots \ldots \ldots \ldots$

Figure 1.3 Location of Thermoluminescent Dosimeters (TLDs) on the NTS, $1997 \ldots \ldots \ldots$

Figure 1.4 Comparative Data for Gross Beta in Air on the NTS . . . . . . . . . . . 6

Figure 1.5 Comparative Data for ${ }^{7} \mathrm{Be}$ in Air on the $\mathrm{NTS} \ldots \ldots \ldots \ldots \ldots \ldots \ldots \ldots \ldots$

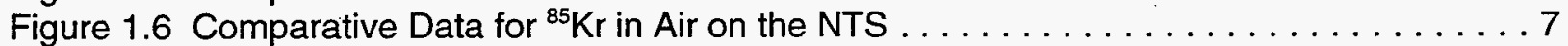

Figure 1.7 Comparative Data for HTO in Air on the NTS . . . . . . . . . . . . . 7 


\section{LIST OF ACRONYMS}

$\begin{array}{ll}\text { C.F.R. } & \text { Code of Federal Regulations } \\ \text { CX } & \text { Categorical Exclusion } \\ \text { CY } & \text { Calendar Year } \\ \text { DCG } & \text { Derived Concentration Guide } \\ \text { DOE } & \text { U.S. Department of Energy } \\ \text { DOE/NV } & \text { DOE Nevada Operations Office } \\ \text { EA } & \text { Environmental Assessment } \\ \text { EDE } & \text { Effective Dose Equivalent } \\ \text { EIS } & \text { Environmental Impact Statement } \\ \text { HTO } & \text { Tritiated Water } \\ \text { LANL } & \text { Los Alamos National Laboratory } \\ \text { MDC } & \text { Minimum Detectable Concentration } \\ \text { NEPA } & \text { National Environmental Policy Act } \\ \text { NTS } & \text { Nevada Test Site } \\ \text { RWMS } & \text { Radioactive Waste Management Site } \\ \text { RWMS-3 } & \text { Radioactive Waste Management Site Area 3 } \\ \text { RWMS-5 } & \text { Radioactive Waste Management Site Area 5 } \\ \text { SDWA } & \text { Safe Drinking Water Act } \\ \text { TLD } & \text { Thermoluminescent Dosimeter } \\ \text { TTR } & \text { Tonopah Test Range }\end{array}$




\subsection{RADIOLOGICAL ENVIRONMENTAL SURVEILLANCE}

\subsection{INTRODUCTION}

The continuing moratorium on the testing of nuclear explosive devices, possibility of alternate uses for the Nevada Test Site (NTS), and reduced budget have led to significant changes in the extent of environmental surveillance activities on and around the NTS. Not only have the number of monitored locations been reduced since 1992, but also the frequency and types of analyses have been changed. The onsite radiological surveillance program is shown in Table 1.1, and this report gives the first quarter results for that program.

During the first calendar quarter of 1997, air samples were collected and analyzed from 45 air particulate sampling stations, 3 noble gas sampling stations, and 12 tritiated water (HTO) vapor sampling stations. Surface water samples were collected and analyzed from one wastewater containment pond and nine sewage lagoons. Groundwater samples were obtained from ten potable supply wells, one non-potable supply well, and seven drinking water distribution end points. Ambient radiation levels were measured at 168 locations. The sampling station locations are shown in Figures 1.1, 1.2, and 1.3. These activities were conducted in accordance with the schedule set forth in Table 1.1.

\subsection{RADIOACTIVITY IN AIR}

The 45 air particulate sampling stations were operated continuously both on the NTS and at offsite locations where airborne radioactivity is believed to be present. Forty-one of the stations were on the NTS, and four were offsite at locations where weapons safety tests were conducted. Samples were collected weekly on glass-fiber filters. After a delay of five to seven days (for radon progeny decay), the filters were counted for gamma, gross alpha, and gross beta activity, composited either monthly or quarterly and then analyzed for ${ }^{238} \mathrm{Pu}$ and ${ }^{239+240} \mathrm{Pu}$. The Radioactive Waste Management Site (RWMS) samples were not analyzed for gross alpha activity.

Samples for the noble gas ${ }^{85} \mathrm{Kr}$ were collected weekly at three fixed locations by compressing air into pressure tanks. A cryogenic distillation process separated the krypton gas from the air sample. It was dissolved in a scintillation cocktail and measured using liquid scintillation counting.

HTO vapor was monitored continuously at 12 locations. Samples were collected every two weeks on silica gel, and the water was extracted, distilled, and analyzed for ${ }^{3} \mathrm{H}$ by use of liquid scintillation counting.

Measured quantities of radioactivity are compared to the Derived Concentration Guides (DCG) found in U.S. Department of Energy (DOE) Order 5400.5 for limiting radiation exposure to the general public. The values used are listed in Table 1.2. In making these comparisons, the most restrictive DCG was used.

\subsubsection{AIR PARTICULATE SAMPLING RESULTS}

The analytical results available by the end of this quarter are discussed below. 


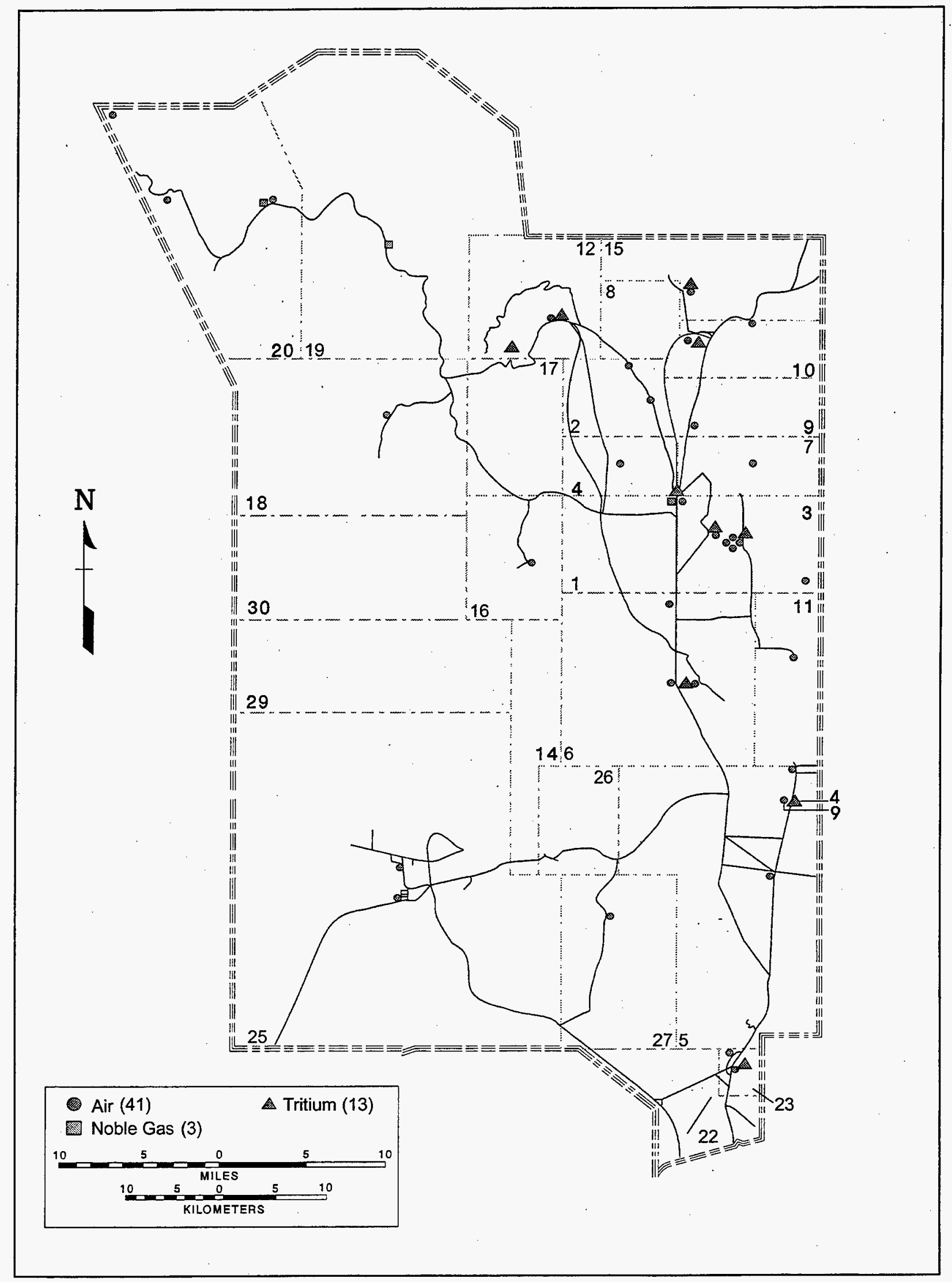

Figure 1.1 Location of NTS Air Sampling Stations, 1997 




Figure 1.2 Location of NTS Water Sampling Stations, 1997 


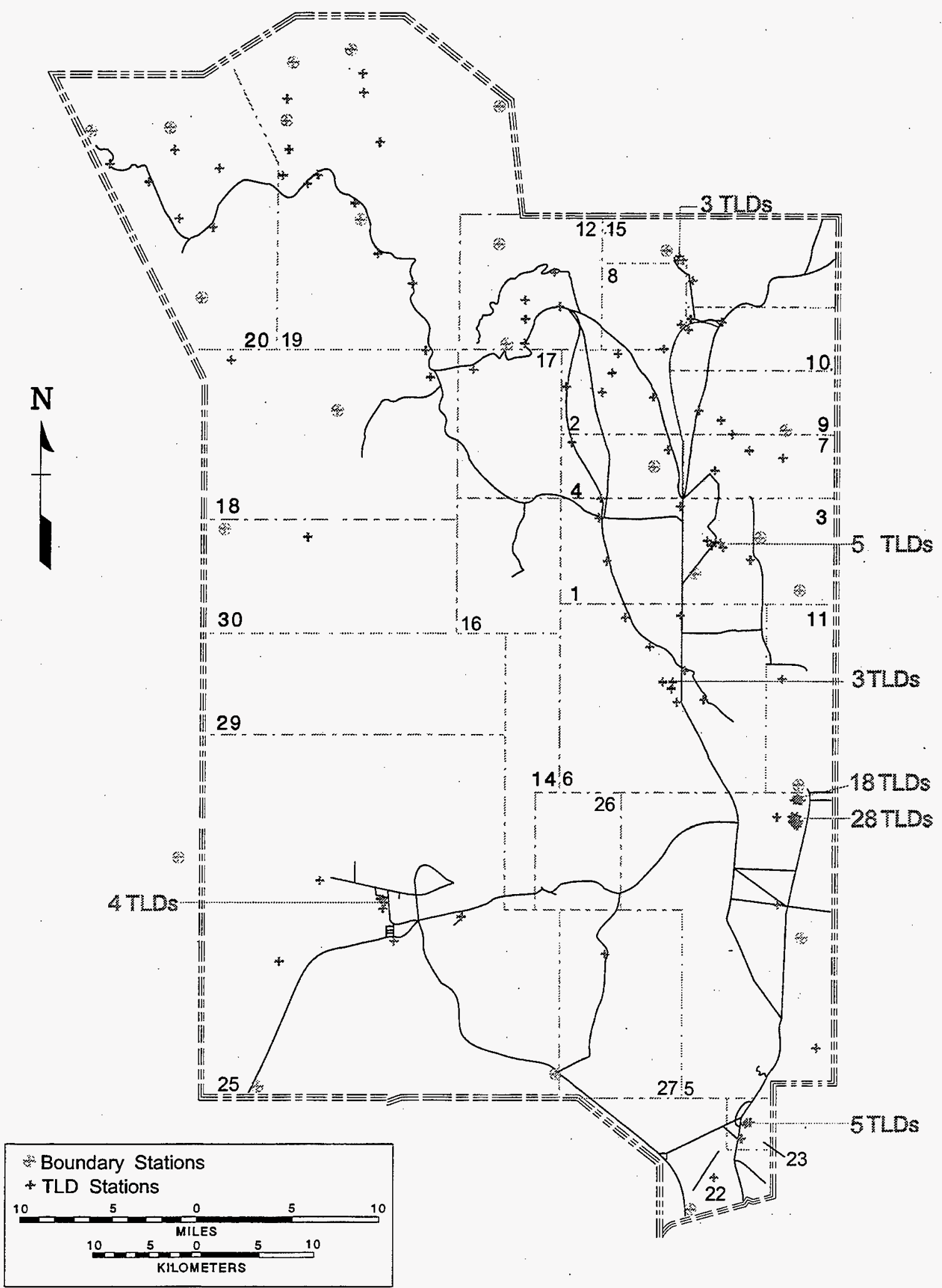

Figure 1.3 Location of Thermoluminescent Dosimeters (TLDs) on the NTS, 1997 


\subsubsection{GROSS ALPHA/BETA AND GAMMA SPECTRAL ANALYSES}

Air particulate samples were held for five to seven days prior to gross alpha/beta counting and gamma spectral analysis to allow for the decay of radon progeny. Summary data for gross beta/alpha and gamma spectral analyses results are shown in Table 1.3. All results exceeded their applicable minimum detectable concentration (MDC). Mean gross beta concentrations ranged from 1.3 to $2.4 \times 10^{-14} \mu \mathrm{Ci} / \mathrm{mL}\left(0.48\right.$ to $\left.0.89 \mathrm{mBq} / \mathrm{m}^{3}\right)$, with a network mean concentration of $1.7 \times 10^{-14} \mu \mathrm{Ci} / \mathrm{mL}\left(0.63 \mathrm{mBq} / \mathrm{m}^{3}\right)$. This concentration is 1.9 percent of the DCG for ${ }^{90} \mathrm{Sr}$ in DOE Order 5400.5 and adjusted to an annual effective dose equivalent (EDE) of 10 mrem (0.1 $\mathrm{mSv}$ ). The network mean is slightly lower than the values observed during the past few years (1989 - 1996), (see Figure 1.4). The gross alpha mean concentration for the network was $1.3 \mathrm{x}$ $10^{-15} \mu \mathrm{Ci} / \mathrm{mL}\left(48 \mu \mathrm{Bq} / \mathrm{m}^{3}\right)$, similar to the 1996 average. Gross alpha analyses were not done on RWMS air samples as mentioned above.

The glass-fiber filters used to collect particulates were analyzed by gamma spectroscopy. All radionuclides detected were naturally occurring in the environment ${ }^{40} \mathrm{~K}$, ${ }^{7} \mathrm{Be}$, and members of the uranium and thorium series). The network mean concentration of ${ }^{7} \mathrm{Be}$ was $2.3 \times 10^{-13} \mu \mathrm{Ci} / \mathrm{mL}$ $\left(8.5 \mathrm{mBq} / \mathrm{m}^{3}\right)$, similar to the averages for the last few years as shown in Figure 1.5.

\subsubsection{NELLIS AIR FORCE RANGE COMPLEX SAMPLES}

The samples collected and analyzed from Area 13 DOUBLE TRACKS and CLEAN SLATE sites were analyzed for gross alpha, gross beta, and gamma activity. The average gross beta result of $1.6 \times 10^{-14} \mu \mathrm{Ci} / \mathrm{mL}\left(0.59 \mathrm{mBq} / \mathrm{m}^{3}\right)$ is similar to the onsite average data, as is the ${ }^{7} \mathrm{Be}$ result of $2.4 \mathrm{x}$ $10^{-13} \mu \mathrm{Ci} / \mathrm{mL}\left(8.9 \mathrm{mBq} / \mathrm{m}^{3}\right)$, from gamma spectrometric analysis of the filters. However, the gross alpha results for these four samplers averaged $1.8 \times 10^{-15} \mu \mathrm{Ci} / \mathrm{mL}\left(67 \mu \mathrm{Bq} / \mathrm{m}^{3}\right)$, slightly higher than the onsite network average.

\subsubsection{PLUTONIUM ANALYSES}

Filters from each particulate sampling station, located on the boundary of the RWMS Area 5 (RWMS-5) (four stations) and RWMS Area 3 (RWMS-3) (four stations), were composited monthly and analyzed for ${ }^{238} \mathrm{Pu}$ and ${ }^{239+240} \mathrm{Pu}$. Filters from all other stations were composited quarterly and analyzed similarly. These analyses, for the first quarter of 1997 , have not been completed for all stations and the results have not been validated.

\subsubsection{NOBLE GAS $\left({ }^{85} \mathrm{Kr}\right)$ SAMPLING RESULTS}

Noble gas analyses for the first quarter of calendar year (CY) 1997 have been completed and the results validated. The available results are shown in Table 1.4. The network average for the three stations sampled this quarter is $24.4 \mathrm{pCi} / \mathrm{m}^{3}\left(0.9 \mathrm{~Bq} / \mathrm{m}^{3}\right)$ of ${ }^{85} \mathrm{Kr}$, which is slightly less than the annual average for the past several years, as shown in Figure 1.6. The two stations on Pahute Mesa had higher biweekly maximum detections than the station at BJY, but the annual average values were not statistically different.

\subsubsection{TRITIATED WATER VAPOR}

Summary data for HTO vapor sampling from the 12 active stations are shown in Table 1.5. Mean station concentrations ranged from 0.58 to $240 \times 10^{-13} \mu \mathrm{Ci} / \mathrm{mL}\left(2.1\right.$ to $\left.890 \mathrm{mBq} / \mathrm{m}^{3}\right)$. The 
Gross Beta in Air



Figure 1.4 Comparative Data for Gross Beta in.Air on the NTS

Beryllium-7 in Air

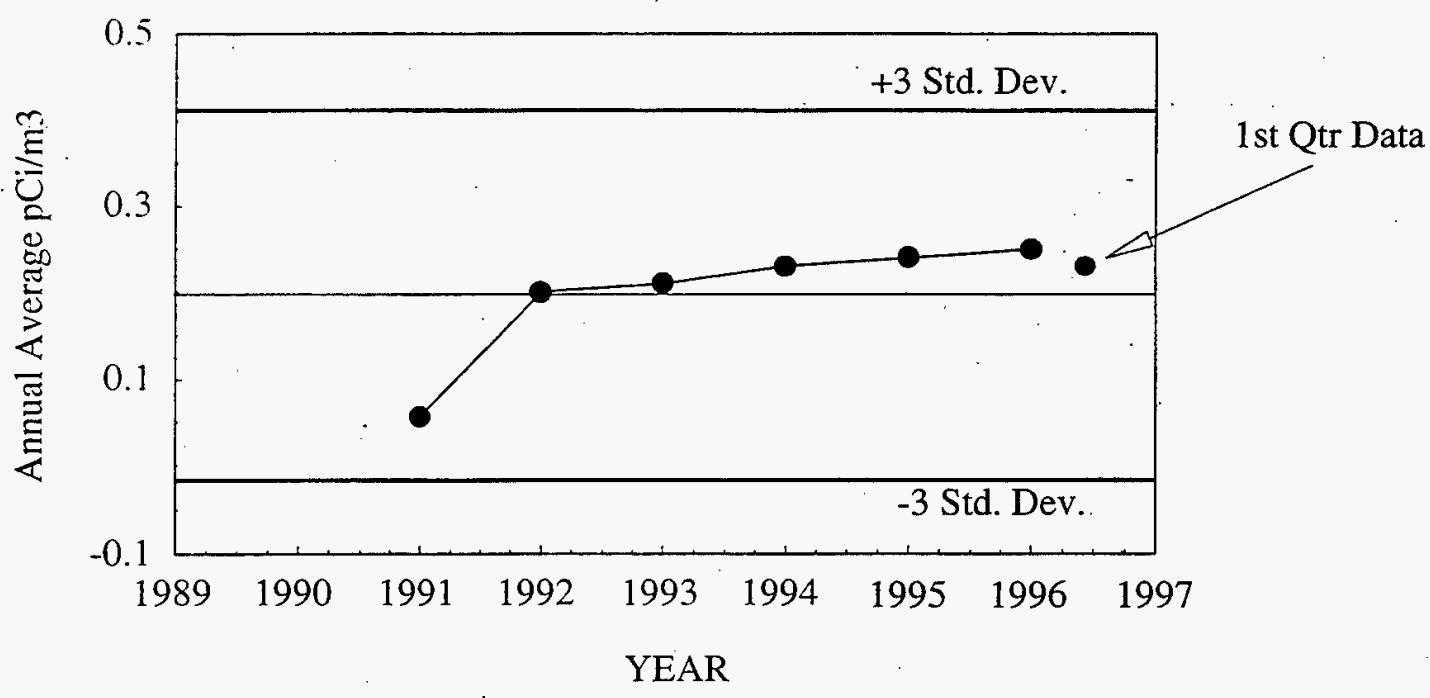

Figure 1.5 Comparative Data for ${ }^{7} \mathrm{Be}$ in Air on the NTS 
Krypton-85 in Air

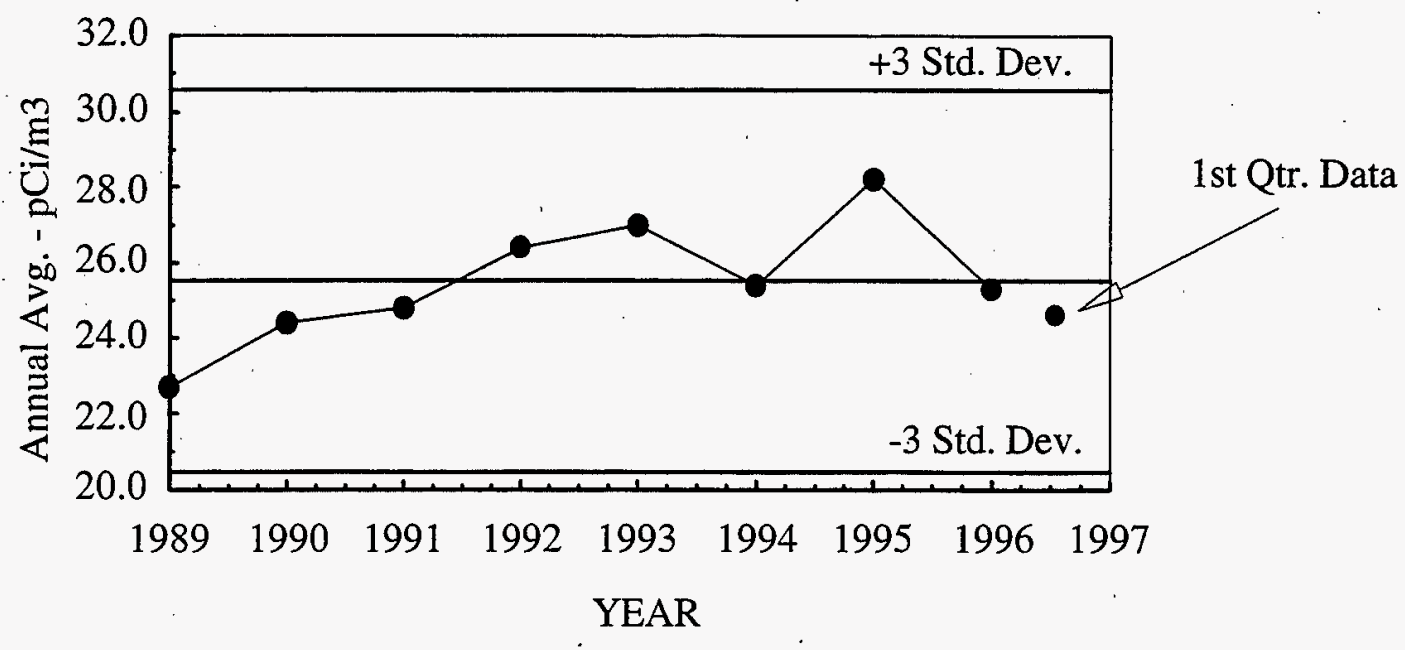

Figure 1.6 Comparative Data for ${ }^{85} \mathrm{Kr}$ in Air on the NTS

HTO in Air

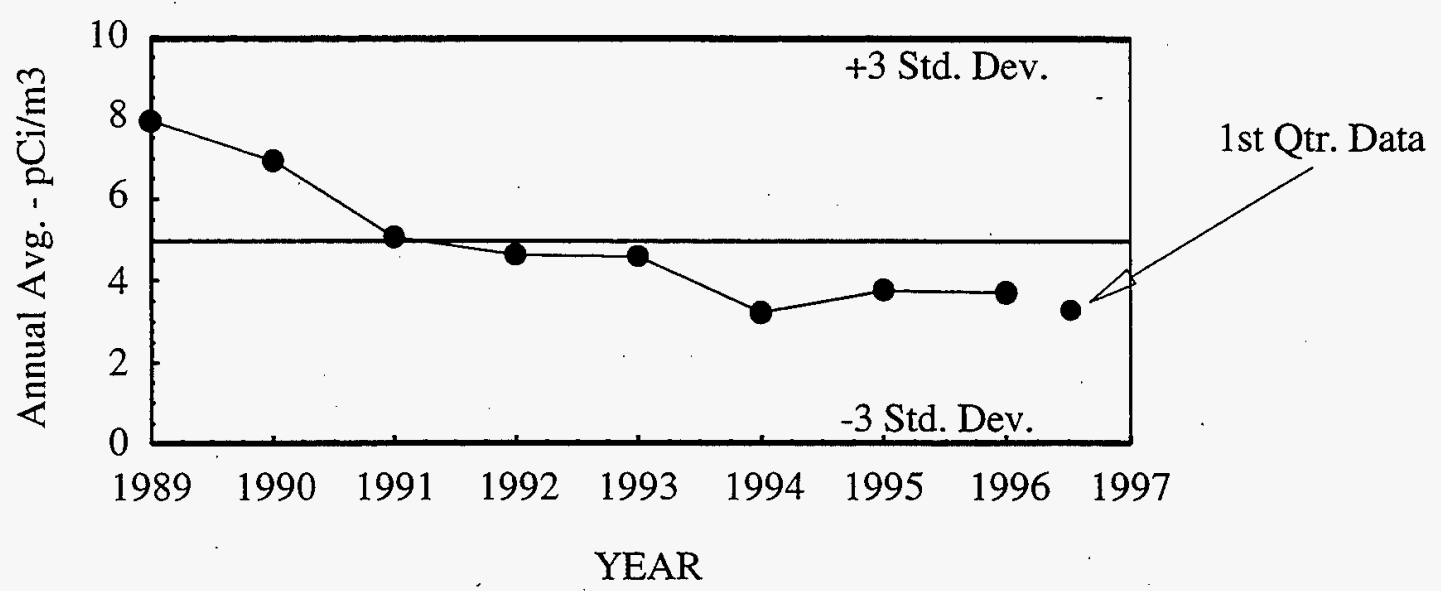

Figure 1.7 Comparative Data for HTO in Air on the NTS 
network mean concentration was $3.4 \times 10^{-12} \mu \mathrm{Ci} / \mathrm{mL}\left(130 \mathrm{mBq} / \mathrm{m}^{3}\right)$. This mean value was consistent with previous measurements, as shown in Figure 7 . The highest mean value was measured at the RWMS-5 No. 8 station and was only 0.24 percent of the DCG for tritium, adjusted for an annual EDE of $10 \mathrm{mrem}$.

\subsection{RADIOACTIVITY IN SURFACE WATER}

Annual samples are taken at all open reservoirs and natural springs. Quarterly samples are taken at the containment ponds and sewage lagoons sampled. All samples are analyzed for gross beta activity, tritium, ${ }^{238} \mathrm{Pu},{ }^{239+240} \mathrm{Pu},{ }^{90} \mathrm{Sr}$, and gamma-emitting nuclides. Containment pond sampling was limited to Area $12 \mathrm{E}$ Tunnel effluent, E Tunnel pond No. 2, and a pond at emplacement well U-3cn. Samples were collected from eight of the nine sewage lagoons.

\subsubsection{CONTAINMENT PONDS}

At the Area 12 E Tunnel complex, grab samples were taken from containment pond No. 2 and at the effluent discharge point. The results of analyses for these two samples are given in

Table 1.6. During pumping postshot Well No. 2 at U-3cn, tritium was detected. The well effluent was pumped into a lined containment pond. A total of $10^{5} \mathrm{gal}\left(3.78 \times 10^{5} \mathrm{~L}\right)$ containing $13.5 \mu \mathrm{Ci} / \mathrm{L}$ of tritium was pumped into the pond.

The results for the $E$ Tunnel complex are generally consistent with the results observed in the samples collected in 1996.

\subsubsection{SEWAGE LAGOONS}

Each of the lagoons is part of a closed system used for evaporative treatment of sanitary waste. The lagoons are located in Areas 6, 11, 12, 22, 23, and 25. Quarterly samples were taken and analyzed for gross beta activity, tritium, ${ }^{238} \mathrm{Pu},{ }^{239+240} \mathrm{Pu}$, and gamma-emitting nuclides. Summary data for sewage lagoons are shown in Table 1.6.

Th gross beta concentrations ranged from 3.2 to $29 \times 10^{-9} \mu \mathrm{Ci} / \mathrm{mL}(0.12$ to $1.2 \mathrm{~Bq} / \mathrm{L})$ with a network mean of $19 \times 10^{-9} \mu \mathrm{Ci} / \mathrm{mL}(0.7 \mathrm{~Bq} / \mathrm{L})$. All results were above the detection limit of $1.5 \times 10^{-9} \mu \mathrm{Ci} / \mathrm{mL}(0.06 \mathrm{~Bq} / \mathrm{L})$. The maximum station mean was at Area 6 Los Alamos National Laboratory (LANL) Pond. These results are consistent with previous data:

The tritium concentrations in sewage lagoon water samples were all less than the median MDC of $700 \mathrm{pCi} / \mathrm{L}(26 \mathrm{~Bq} / \mathrm{L})$, for conventional tritium analyses.

Station ${ }^{238} \mathrm{Pu}$ and ${ }^{239+240} \mathrm{Pu}$ maximum concentrations were $-0.0018 \times 10^{-9} \mu \mathrm{Ci} / \mathrm{mL}$ and $0.21 \times 10^{-9}$ $\mu \mathrm{Ci} / \mathrm{mL}(-0.067$ and $0.78 \mathrm{mBq} / \mathrm{L})$, respectively. All of the ${ }^{238} \mathrm{Pu}$ and ${ }^{239+240} \mathrm{Pu}$ results, except for those at the LANL and Area 23 lagoons, were less than the median MDC, as has been observed previously.

Analyses are performed annually for ${ }^{90} \mathrm{Sr}$ in sewage lagoons. These analyses were not performed in this quarter of 1997.

All water samples were analyzed by gamma spectroscopy. The only radionuclides detected were naturally occurring in the environment $\left({ }^{40} \mathrm{~K},{ }^{7} \mathrm{Be}\right.$, and members of the uranium and thorium series). 
The results for sewage lagoons discussed above are comparable with past results, and the network means are within the ranges measured during the past six years.

\subsection{RADIOACTIVITY IN SUPPLY WELL WATER}

The NTS water system currently consists of 11 supply wells, 10 of which supply potable water to onsite distribution systems. One supply well, Well UE-5c in Area 5, supplies water for industrial purposes.

The potable supply wells are sampled quarterly and analyzed for gross alpha activity, gross beta activity, tritium (using enrichment procedure), ${ }^{238} \mathrm{Pu},{ }^{239+240} \mathrm{Pu},{ }^{90} \mathrm{Sr},{ }^{226+228} \mathrm{Ra}$, and gamma-emitting nuclides. The pump for Area 6 Well $\mathrm{C}$ was broken in 1996, and this potable supply well has not been sampled since then. The non-potable well was also sampled quarterly and received the same analyses, except for tritium (standard liquid scintillation used) and ${ }^{226+228} \mathrm{Ra}$ (none). Summary data for these supply wells are given in Table 1.6.

\subsubsection{GROSS BETA}

The station values for gross beta for potable supply wells ranged from 2.7 to $12 \times 10^{-9} \mu \mathrm{Ci} / \mathrm{mL}$ (0.1 to $0.48 \mathrm{~Bq} / \mathrm{L})$, with a network mean of $7.0 \times 10^{-9} \mu \mathrm{Ci} / \mathrm{mL}(0.26 \mathrm{~Bq} / \mathrm{L})$. The gross beta result for the non-potable supply well was $6.7 \times 10^{-9} \mu \mathrm{Ci} / \mathrm{mL}(0.25 \mathrm{~Bq} / \mathrm{L})$. All results were above the detection limits The maximum potable station value was at Area 5 Well $5 \mathrm{~B}$ and was 4 percent of the Safe Drinking Water Act (SDWA) compliance limit for ${ }^{40} \mathrm{~K}$.

\subsubsection{TRITIUM}

The station values for tritium for potable supply wells ranged from 3.8 to $9.4 \times 10^{-9} \mu \mathrm{Ci} / \mathrm{mL}$ ( 0.14 to $0.35 \mathrm{~Bq} / \mathrm{L})$, with a network mean of $6.7 \times 10^{-9} \mu \mathrm{Ci} / \mathrm{mL}(0.23 \mathrm{~Bq} / \mathrm{L})$. The tritium result for the non-potable supply well was $6.2 \times 10^{-9} \mu \mathrm{Ci} / \mathrm{mL}(0.23 \mathrm{~Bq} / \mathrm{L})$. Most results were less than the detection limit. The maximum tritium value was at Well $\mathrm{J}-13$ and was 0.01 percent of the SDWA compliance limit.

\subsubsection{PLUTONIUM}

The sample results for ${ }^{238} \mathrm{Pu}$ for all supply wells were less than the median MDC, as has usually been observed in these samples. There was only one result for ${ }^{239+240} \mathrm{Pu}$ that exceeded the detection limits. That result was $7.2 \times 10^{-11} \mu \mathrm{Ci} / \mathrm{mL}(2.7 \mathrm{mBq} / \mathrm{L})$, at Well $\mathrm{J}-12$ and is 7.2 percent of the SDWA limit.

\subsubsection{GROSS ALPHA \& RADIUM}

The station values for gross alpha for potable supply wells ranged from 0.74 to $10 \times 10^{-9} \mu \mathrm{Ci} / \mathrm{mL}$ (27 to $370 \mathrm{mBq} / \mathrm{L})$, with a network mean of $6.5 \times 10^{-9} \mu \mathrm{Ci} / \mathrm{mL}(240 \mathrm{mBq} / \mathrm{L})$. The gross alpha value for the non-potable supply well was $10 \times 10^{-9} \mu \mathrm{Ci} / \mathrm{mL}(0.37 \mathrm{~Bq} / \mathrm{L})$. All results were above the detection limit. Several potable supply well results exceeded the SDWA screening level for gross alpha of $5 \mathrm{pCi} / \mathrm{L}$. 
The potable supply well values for ${ }^{226} \mathrm{Ra}$ ranged from -0.98 to $1.7 \times 10^{-9} \mu \mathrm{Ci} / \mathrm{mL}$ (-36 to 63 $\mathrm{mBq} / \mathrm{L})$, with a network mean of $1.4 \times 10^{-9} \mu \mathrm{Ci} / \mathrm{mL}(52 \mathrm{mBq} / \mathrm{L})$. The network mean for ${ }^{228} \mathrm{Ra}$ of $0.22 \times 10^{-9} \mu \mathrm{Ci} / \mathrm{mL}(8 \mathrm{mBq} / \mathrm{L})$ was less than the $\mathrm{MDC}$, as were all individual well sample results. The highest ${ }^{226} \mathrm{Ra}$ result was at Well $\mathrm{C}-1$. This result was 34 percent of the applicable adjusted DCG.

\subsubsection{STRONTIUM}

The maximum station value for potable supply wells for ${ }^{90} \mathrm{Sr}$ was $0.14 \times 10^{-9} \mu \mathrm{Ci} / \mathrm{mL}(5.2 \mathrm{mBq} / \mathrm{L})$, but the network mean was less than the MDC for analysis. The result for the industrial supply well was also less than the MDC. All results were below the detection limits.

\subsubsection{GAMMA SPECTROSCOPY}

All water samples were analyzed by gamma spectroscopy. The only radionuclides detected were naturally occurring in the environment $\left({ }^{40} \mathrm{~K},{ }^{7} \mathrm{Be}\right.$, and members of the uranium and thorium series).

The results for supply wells discussed above are generally comparable with past results. Network means were within the range of means measured during the past six years, except for the ${ }^{90} \mathrm{Sr}$ concentrations, which are generally lower than have been observed previously.

\subsection{RADIOACTIVITY IN DRINKING WATER}

As a check on any effect the water distribution system might have on water quality, seven drinking water distribution end-points (tap water) were sampled.

These end-points are sampled quarterly at convenient water taps and analyzed for gross alpha and beta activity, tritium, ${ }^{238} \mathrm{Pu},{ }^{239+240} \mathrm{Pu}$, and gamma-emitting nuclides. Summary data for the tap water are given in Table 1.7. Results greater than their detection limit are compared to the DCGs in DOE 5400.5 as adjusted to meet federal SDWA regulations, or SDWA compliance or screening levels.

\subsubsection{GROSS BETA}

The tap water values for gross beta ranged from 2.9 to $9.2 \times 10^{-9} \mu \mathrm{Ci} / \mathrm{mL}(0.1$ to $0.33 \mathrm{~Bq} / \mathrm{L})$, with a network mean of $5.9 \times 10^{-9} \mu \mathrm{Ci} / \mathrm{mL}(0.22 \mathrm{~Bq} / \mathrm{L})$. All values were above the detection limits. The maximum tap water value, at Area 25 Building 4221 was 3 percent of the SDWA compliance limit, based on the ${ }^{40} \mathrm{~K}$ limit. All results were almost identical to the 1996 values.

\subsubsection{TRITIUM}

The station values for tritium ranged from -130 to $240 \times 10^{-9} \mu \mathrm{Ci} / \mathrm{mL}(-4.8$ to $8.9 \mathrm{~Bq} / \mathrm{L})$, with a network mean of $28 \times 10^{-9} \mu \mathrm{Ci} / \mathrm{mL}(1.0 \mathrm{~Bq} / \mathrm{L})$. All results were less than the detection limits.

\subsubsection{PLUTONIUM}

All concentrations of both ${ }^{239+240} \mathrm{Pu}$ and ${ }^{238} \mathrm{Pu}$ were less than the respective median MDCs, as has been observed in previous samples for this network. 


\subsubsection{GROSS ALPHA}

The sample results for gross alpha ranged from 0.35 to $7.6 \times 10^{-9} \mu \mathrm{Ci} / \mathrm{mL}(0.13$ to $0.28 \mathrm{~Bq} / \mathrm{L})$, with a network mean of $4.7 \times 10^{-9} \mu \mathrm{Ci} / \mathrm{mL}(0.17 \mathrm{~Bq} / \mathrm{L})$, similar to the 1996 data. All results were above the detection limit, except for Building 12-23.

\subsubsection{STRONTIUM}

Analyses are performed annually for ${ }^{90} \mathrm{Sr}$ in consumption end-points and were not done this quarter.

\subsubsection{GAMMA SPECTROSCOPY}

All water samples were analyzed by gamma spectroscopy. The only radionuclides detected were naturally occurring in the environment $\left({ }^{40} \mathrm{~K},{ }^{7} \mathrm{Be}\right.$, and members of the uranium and thorium series).

The results for tap water samples discussed above are generally comparable with past results. All network means are within the range of means measured during the past few years.

\subsection{NON-RADIOLOGICAL EFFLUENT MONITORING}

\subsection{DRINKING WATER SYSTEMS}

Water sampling was conducted for analysis of bacteria in the water as required by the federal SDWA and state of Nevada regulations. Samples were taken at various locations throughout all drinking water distribution systems on the NTS. Common sampling points were restrooms and cafeteria sinks. Samples were also collected this quarter for inorganic and organic analyses. All analyses were performed in accordance with Nevada Administrative Code 445A.450 ff. and Title 40 C.F.R. Part 141.

\subsubsection{BACTERIOLOGICAL SAMPLING}

All water systems were tested once a month, with the number of people being served, determining the number of samples collected. All samples were analyzed for the presence of coliform bacteria. Residual chlorine analyses are no longer required by the state.

No coliform bacteria were detected in any sample collected during the first quarter of 1997 .

\subsubsection{CHEMICAL ANALYSIS}

During the first quarter of 1997, all systems were sampled and analyzed for nitrates, lead, and copper. All sample results were below the maximum concentration levels, but nitrate levels in the two Area 25 wells exceeded the action level of $5 \mathrm{ppm}$ for nitrate. As a result, samples will have to be collected and analyzed for nitrate in each of the next four quarters. 
Also this quarter, Wells $4 a$ and $5 b$ were sampled for volatile organic compounds, and all results were satisfactory. The wells in Area 25 were also sampled for fluoride, as required by a waiver granted by the state. The fluoride results were all acceptable.

\subsection{SEWAGE LAGOONS}

During the first quarter of 1997, sampling was conducted for sewage lagoon systems at the NTS, in accordance with state of Nevada General Permit, GNEV93001. Water parameters monitored included water depth in infiltration basins, monitoring of influent quality, and organic loading rates in sewage lagoons. The results for water depth measurements are shown in Table 1.8, influent quality data are shown in Table 1.9, and the results of organic loading rates are shown in Table 1.10. The results and data in these three tables are all within permit limits.

The permit also requires sampling and analysis of infiltration basins which contain $30 \mathrm{~cm}$ or more of liquid in January and June of any year. The Area 6 Yucca Lake facility level exceeded the 30 $\mathrm{cm}$ limit during January of this year. The analytic results were all below compliance limits and are shown in Table 1.11.

\subsection{NON-HAZARDOUS SOLID WASTE DISPOSAL}

Monitoring of the three sanitary landfills was limited to recording daily refuse amounts by weight. All waste disposed of in the Area 23 landfill was weighed at the Gate 100 weighing station. Waste disposed of in the Area $910 \mathrm{c}$ crater landfill was weighed at the landfill site. Approximately 1,785 tons of waste were disposed of in the Areas 6,9 , and 23 sanitary landfills during the first quarter of 1997, as shown in Table 1.12.

\subsection{NATIONAL ENVIRONMENTAL POLICY ACT}

The National Environmental Policy Act (NEPA) of 1969 requires all federal facilities, including the NTS, to account for environmental impacts and potential alternatives in conducting and planning their operations. In accordance with NEPA, DOE Nevada Operations Office (DOE/NV) activities are evaluated for their potential environmental impacts and to ensure that the proper level of NEPA documentation is initiated. During the first quarter of 1997, NTS-related NEPA activities included actions on three Environmental Impact Statements (EISs), five Environmental Assessments (EAs), and seven Categorical Exclusions (CXs). Of these, six CXs were initiated in the first quarter of 1997. These NEPA documents are listed in chronological order in Table 1.13, with their assigned number and present status.

\subsection{OCCURRENCE REPORTING}

Occurrences are environmental, health, and/or safety-related events which are reported in several categories in accordance with the requirements of DOE Order 5000.3B. One Environmental Occurrence was reported for NTS facilities during the first quarter of 1997. Details for this occurrence, including report number, description, and status, appear in Table 1.14. 
TABLES 
Table 1.1 Network Collection and Analysis Data

Frequency of Analyses

\begin{tabular}{|c|c|c|c|c|c|c|}
\hline Network & Media & No. & Weekly & Monthly & Quarterly & Annually \\
\hline Air & $\begin{array}{l}\text { Particulate } \\
\text { On Nellis Range } \\
\text { RWMS } \\
\text { Tritium } \\
\text { Noble Gas }\end{array}$ & $\begin{array}{r}28 \\
4 \\
13 \\
12 \\
3\end{array}$ & $\begin{array}{l}\alpha, \beta, \gamma \\
\alpha, \beta, \gamma \\
\beta, \gamma \\
{ }^{85} \mathrm{Kr}\end{array}$ & $\begin{array}{l}\mathrm{Pu} \\
\text { Bi-weekly }\end{array}$ & $\begin{array}{l}\mathrm{Pu} \\
\mathrm{Pu}\end{array}$ & \\
\hline Water & $\begin{array}{l}\text { Reservoir } \\
\text { Springs } \\
\text { Wells } \\
\text { Spigot } \\
\text { Sewage } \\
\text { Pond }\end{array}$ & $\begin{array}{r}15 \\
8 \\
12 \\
\\
7 \\
9 \\
2\end{array}$ & & & $\begin{array}{c}\beta, \gamma, \alpha,{ }^{3} \mathrm{H}+, \mathrm{Sr} \\
\mathrm{Pu},{ }^{226,228} \mathrm{Ra} \\
\beta, \gamma, \alpha,{ }^{3} \mathrm{H}, \mathrm{Pu} \\
\beta, \gamma,{ }^{3} \mathrm{H}, \mathrm{Pu} \\
\beta, \gamma,{ }^{3} \mathrm{H}, \mathrm{Pu}\end{array}$ & $\begin{array}{l}\beta, \gamma,{ }^{3} \mathrm{H}, \mathrm{Sr}, \mathrm{Pu} \\
\beta, \gamma,{ }^{3} \mathrm{H}, \mathrm{Sr}, \mathrm{Pu}\end{array}$ \\
\hline TLD & Environment & 168 & & $y$ & & \\
\hline
\end{tabular}

Table 1.2 Derived Limits for Radionuclides in Air and Water

$\mu \mathrm{Ci} / \mathrm{mL}$

Radionuclide



$\underline{D C G}\left(\right.$ air) ${ }^{(a)}$

$1 \times 10^{-08}$
$9 \times 10^{-11}$
$3 \times 10^{-7(c)}$
$9 \times 10^{-13}$
$1 \times 10^{-13}$
$3 \times 10^{-15}$
$2 \times 10^{-15}$

$\underline{\mathrm{DCG}}$ (water) $^{(\mathrm{b})}$

$8 \times 10^{-5}$

$3 \times 10^{-7}$

$--$

$4 \times 10^{-8}$

$4 \times 10^{-9}$

$2 \times 10^{-9}$

$1 \times 10^{-9}$

(a) DCG - Derived Concentration Guides are reference values for conducting radiological protection programs at operational DOE facilities and sites. The DCG values for air are for an EDE of $10 \mathrm{mrem}(0.1 \mathrm{mSv})$ (inhalation) for a year as required by Title 40 C.F.R. 61.92 and DOE Order 5400.5.

(b) The values listed for beta and photon emitters in the table are based on 4 mrem committed EDE for the radionuclide taken into the body by ingestion of water during one year $(730 \mathrm{~L})$. Gross beta levels less than or equal to $50 \mathrm{pCi} / \mathrm{L}$ are in compliance with Title 40 C.F.R. 141, SDWA.

(c) Nonstochastic value. 
Table 1.3 Average Gross Alpha, Gross Beta, and ${ }^{7} \mathrm{Be}$ in Air ( $\left.\mu \mathrm{Ci} / \mathrm{mL}\right)$ - First Quarter, CY 1997

\section{Location}

Area 1 BJY

Area 2

Area 2-1 Substation

Area 3 Mudplant

Area 3 U-3ah/at S

Area $3 \mathrm{U}$-3ah/at E

Area $3 \mathrm{U}-3 a h / a t \mathrm{~N}$

Area 3 U-3ah/at W

Area 3 Well ER-3-1

Area 4 Bunker T-4

Area 5 RWMS\#1

Area 5 RWMS\#4

Area 5 RWMS\#6

Area 5 RWMS\#8

Area 5 RWMS Pit-5

Area 5 TRU Building N

Area 5 TRU Building $S$

Area 5 WEF S

Area 5 WEF N

Area 5 DOD

Area 5 Well 5B

Area 6 YUCCA

Area 6 CP-6

Area 6 Well 3

Area 7 UE-7ns

Area 9-300

Area 10 Gate $700 \mathrm{~S}$

Area 10 SEDAN Crater

Area 11 Gate 293

Area 12

Area 15 EPA Farm

Area 163545 Substation

Area 18 Well UE-18t

Area 20 SCHOONER

Area 20 CABRIOLET

Area 20

Area 23 Building 790\#2

Area $23 \mathrm{H} \& S$ Building

Area 25 E-MAD N

Area 25 NRDS

Area 27

Network Averages

Average MDC
Gross $\alpha$

$1.2 \times 10^{-15}$
$1.3 \times 10^{-15}$
$1.2 \times 10^{-15}$
$1.3 \times 10^{-15}$

$1.4 \times 10^{-15}$

$1.3 \times 10^{-15}$

$1.8 \times 10^{-15}$

$1.4 \times 10^{-15}$

$1.1 \times 10^{-15}$

$1.5 \times 10^{-15}$

$1.4 \times 10^{-15}$

$1.3 \times 10^{-15}$

$1.4 \times 10^{-15}$

$1.1 \times 10^{-15}$

$1.4 \times 10^{-15}$

$1.3 \times 10^{-15}$

$1.1 \times 10^{-15}$

$1.1 \times 10^{-15}$

$1.0 \times 10^{-15}$

$1.1 \times 10^{-15}$

$1.0 \times 10^{-15}$

$1.3 \times 10^{-15}$

$1.1 \times 10^{-15}$

$1.9 \times 10^{-15}$

$1.0 \times 10^{-15}$

$1.3 \times 10^{-15}$

$1.2 \times 10^{-15}$

$1.2 \times 10^{-15}$

$1.3 \times 10^{-15}$

$1.6 \times 10^{-15}$

$1.3 \times 10^{-15}$

$9.9 \times 10^{-16}$

\section{Gross $\beta$}

$1.7 \times 10^{-14}$

$1.7 \times 10^{-14}$

$1.6 \times 10^{-14}$

$1.7 \times 10^{-14}$

$1.5 \times 10^{-14}$

$1.6 \times 10^{-14}$

$1.8 \times 10^{-14}$

$1.5 \times 10^{-14}$

$1.8 \times 10^{-14}$

$1.8 \times 10^{-14}$

$1.7 \times 10^{-14}$

$2.0 \times 10^{-14}$

$1.8 \times 10^{-14}$

$1.9 \times 10^{-14}$

$1.9 \times 10^{-14}$

$2.4 \times 10^{-14}$

$1.9 \times 10^{-14}$

$1.8 \times 10^{-14}$

$1.8 \times 10^{-14}$

$1.4 \times 10^{-14}$

$2.1 \times 10^{-14}$

$1.9 \times 10^{-14}$

$1.8 \times 10^{-14}$

$1.9 \times 10^{-14}$

$1.6 \times 10^{-14}$

$1.7 \times 10^{-14}$

$1.8 \times 10^{-14}$

$1.7 \times 10^{-14}$

$1.7 \times 10^{-14}$

$1.5 \times 10^{-14}$

$1.6 \times 10^{-14}$

$1.6 \times 10^{-14}$

$1.6 \times 10^{-14}$

$1.6 \times 10^{-14}$

$1.6 \times 10^{-14}$

$1.3 \times 10^{-14}$

$1.8 \times 10^{-14}$

$1.7 \times 10^{-14}$

$1.6 \times 10^{-14}$

$1.8 \times 10^{-14}$

$1.4 \times 10^{-14}$

$1.7 \times 10^{-14}$

$2.7 \times 10^{-15}$
Beryllium-7

$2.4 \times 10^{-13}$

$2.5 \times 10^{-13}$

$2.2 \times 10^{-13}$

$2.2 \times 10^{-13}$

$2.0 \times 10^{-13}$

$2.3 \times 10^{-13}$

$2.6 \times 10^{-13}$

$2.2 \times 10^{-13}$

$2.4 \times 10^{-13}$

$2.5 \times 10^{-13}$

$2.4 \times 10^{-13}$

$2.7 \times 10^{-13}$

$2.6 \times 10^{-13}$

$2.8 \times 10^{-13}$

$2.4 \times 10^{-13}$

$2.7 \times 10^{-13}$

$2.1 \times 10^{-13}$

$2.2 \times 10^{-13}$

$2.3 \times 10^{-13}$

$1.9 \times 10^{-13}$

$2.5 \times 10^{-13}$

$2.5 \times 10^{-13}$

$2.3 \times 10^{-13}$

$2.7 \times 10^{-13}$

$2.3 \times 10^{-13}$

$2.3 \times 10^{-13}$

$2.8 \times 10^{-13}$

$2.5 \times 10^{-13}$

$2.2 \times 10^{-13}$

$2.1 \times 10^{-13}$

$2.2 \times 10^{-13}$

$2.5 \times 10^{-13}$

$2.4 \times 10^{-13}$

$2.2 \times 10^{-13}$

$2.2 \times 10^{-15}$

$2.0 \times 10^{-13}$

$2.4 \times 10^{-13}$

$2.4 \times 10^{-13}$

$2.3 \times 10^{-13}$

$2.6 \times 10^{-13}$

$2.2 \times 10^{-13}$

$2.3 \times 10^{-13}$

$7.9 \times 10^{-14}$ 
Table 1.4 Offsite Particulate and Onsite ${ }^{85} \mathrm{Kr}$ in Air Summary Data - First Quarter, CY 1997

\section{OFFSITE PARTICULATE RESULTS ( $\mu \mathrm{Ci} / \mathrm{mL})$}

\begin{tabular}{llll} 
Location & Gross Alpha & Gross Beta & Beryllium-7 \\
\cline { 2 - 3 } Area 13 Project 57 & $1.6 \times 10^{-15}$ & $1.7 \times 10^{-14}$ & $2.2 \times 10^{-13}$ \\
Area 52 DOUBLE TRACKS & $1.7 \times 10^{-15}$ & $1.6 \times 10^{-14}$ & $2.2 \times 10^{-13}$ \\
TTR CLEAN SLATE I & $1.7 \times 10^{-15}$ & $1.7 \times 10^{-14}$ & $2.6 \times 10^{-13}$ \\
TTR CLEAN SLATE III & $2.0 \times 10^{-15}$ & $1.6 \times 10^{-14}$ & $2.4 \times 10^{-13}$ \\
Average & & & \\
Average MDC & $1.8 \times 10^{-15}$ & $1.6 \times 10^{-14}$ & $2.4 \times 10^{-13}$ \\
& $9.9 \times 10^{-16}$ & $2.7 \times 10^{-15}$ & $7.9 \times 10^{-14}$
\end{tabular}

\section{ONSITE KRYPTON-85 RESULTS ( $\mu \mathrm{Ci} / \mathrm{mL})$}

Location $\quad$ Average $\quad$ Maximum $\quad$ Minimum

Area 1 BJY

$3.0 \times 10^{-11}$

$3.5 \times 10^{-11}$

$1.6 \times 10^{-11}$

Area 19 Pahute Substa

$2.5 \times 10^{-11}$

$3.8 \times 10^{-11}$

$9.2 \times 10^{-12}$

Area 20 Camp

$2.9 \times 10^{-11}$

$4.1 \times 10^{-11}$

$4.4 \times 10^{-12}$

All Sites

$2.8 \times 10^{-11}$

$4.1 \times 10^{-11}$

$4.4 \times 10^{-12}$

Table 1.5 Tritium in Atmospheric Moisture Summary Data $(\mu \mathrm{Ci} / \mathrm{mL})$ - First Quarter, CY 1997

Location

Area 1 BJY

Area 3 Mud Plant

Area 3 U-3ah/at N

Area 5 RWMS 1

Area 5 RWMS 4

Area 5 RWMS 6

Area 5 RWMS 8

Area 10 SEDAN Crater

Area 12 Camp

Area 12 E Tunnel Pond

Area 15 EPA Farm

Area $23 \mathrm{H}$ \& S Building

All Sites
Average

$3.92 \times 10^{-13}$

$3.48 \times 10^{-13}$

$1.10 \times 10^{-13}$

$1.72 \times 10^{-12}$

$1.77 \times 10^{-12}$

$1.37 \times 10^{-12}$

$2.40 \times 10^{-11}$

$2.78 \times 10^{-12}$

$5.83 \times 10^{-14}$

$2.86 \times 10^{-12}$

$5.18 \times 10^{-12}$

$8.31 \times 10^{-14}$

$3.36 \times 10^{-12}$
Maximum

Minimum

$1.07 \times 10^{-12}$

$1.62 \times 10^{-12}$

$5.69 \times 10^{-13}$

$3.64 \times 10^{-12}$

$3.74 \times 10^{-12}$

$2.89 \times 10^{-12}$

$1.12 \times 10^{-10}$

$6.35 \times 10^{-12}$

$9.46 \times 10^{-13}$

$5.07 \times 10^{-12}$

$9.35 \times 10^{-12}$

$7.19 \times 10^{-13}$

$-3.80 \times 10^{-13}$

$-6.44 \times 10^{-13}$

$-1.44 \times 10^{-12}$

$4.87 \times 10^{-13}$

$3.93 \times 10^{-13}$

$-3.17 \times 10^{-13}$

$1.77 \times 10^{-13}$

$1.49 \times 10^{-15}$

$-5.59 \times 10^{-13}$

$-1.42 \times 10^{-13}$

$1.91 \times 10^{-12}$

$-1.13 \times 10^{-12}$

$2.40 \times 10^{-11}$

$-8.31 \times 10^{-14}$ 
Table 1.6 Summary Data for Well and Surface Water Samples - First Quarter, CY 1997

\section{GROUND WATER ( $\mu \mathrm{Ci} / \mathrm{mL})$}

\begin{tabular}{|c|c|c|c|c|c|c|c|c|}
\hline Well Name & $\begin{array}{l}\text { Gross } \\
\text { Alpha }\end{array}$ & $\begin{array}{l}\text { Gross } \\
\text { Beta }\end{array}$ & $\stackrel{238}{\underline{P u}}$ & ${ }^{239+240} \mathrm{Pu}$ & ${ }^{90} \mathrm{Sr}$ & $\begin{array}{l}\text { Enrich. } \\
\text { Tritium }\end{array}$ & ${ }^{226} \mathrm{Ra}$ & ${ }^{228} \mathrm{Ra}$ \\
\hline \multicolumn{9}{|c|}{ Potable Wells } \\
\hline ell 5B & $5.5 \times 10^{-09}$ & $1.2 \times 10^{-08}$ & $-2.6 \times 10^{-13}$ & $8.5 \times 10^{-11}$ & $-3.3 \times 10^{-11}$ & $7.4 \times 10^{-09}$ & $-9.8 \times 10^{-10}$ & $2.7 \times 10^{-10}$ \\
\hline ell 5C & $8.0 \times 10^{-09}$ & $5.9 \times 10^{-09}$ & $3.2 \times 10^{-12}$ & $-1.2 \times 10^{-12}$ & $-1.0 \times 10^{-10}$ & $7.1 \times 10^{-09}$ & $9.4 \times 10^{-10}$ & $3.7 \times 10^{-10}$ \\
\hline Well 4A & $1.2 \times 10^{-08}$ & $8.2 \times 10^{-09}$ & $-1.2 \times 10^{-12}$ & $-3.6 \times 10^{-12}$ & $-1.3 \times 10^{-10}$ & $4.0 \times 10^{-09}$ & $-2.5 \times 10^{-10}$ & $3.8 \times 10^{-10}$ \\
\hline ell 4 & $1.0 \times 10^{-08}$ & $8.0 \times 10^{-09}$ & $-1.4 \times 10^{-12}$ & $-3.9 \times 10^{-14}$ & $-9.0 \times 10^{-11}$ & $6.8 \times 10^{-09}$ & $-7.9 \times 10^{-10}$ & $2.7 \times 10^{-10}$ \\
\hline Well C-1 & $8.0 \times 10^{-09}$ & $9.6 \times 10^{-09}$ & $-1.1 \times 10^{-12}$ & $-3.2 \times 10^{-12}$ & $-4.8 \times 10^{-11}$ & $8.5 \times 10^{-09}$ & $1.7 \times 10^{-09}$ & $8.8 \times 10^{-10}$ \\
\hline Well UE-16d & $1.0 \times 10^{-08}$ & $8.7 \times 10^{-09}$ & $-1.4 \times 10^{-12}$ & $-3.8 \times 10^{-14}$ & $1.4 \times 10^{-10}$ & $7.0 \times 10^{-09}$ & $7.8 \times 10^{-10}$ & $5.7 \times 10^{-11}$ \\
\hline Well HTH 8 & $7.4 \times 10^{-10}$ & $2.7 \times 10^{-09}$ & $-2.1 \times 10^{-12}$ & $4.8 \times 10^{-11}$ & $-9.8 \times 10^{-11}$ & $3.8 \times 10^{-09}$ & $5.2 \times 10^{-10}$ & $-6.5 \times 10^{-11}$ \\
\hline Well Army \#1 & $4.3 \times 10^{-09}$ & $6.3 \times 10^{-09}$ & $2.0 \times 10^{-12}$ & $1.5 \times 10^{-11}$ & $8.0 \times 10^{-11}$ & $7.5 \times 10^{-09}$ & $-5.6 \times 10^{-10}$ & $1.3 \times 10^{-10}$ \\
\hline Well J-12 & $1.3 \times 10^{-09}$ & $4.8 \times 10^{-09}$ & $4.7 \times 10^{-13}$ & $7.2 \times 10^{-11}$ & $-7.0 \times 10^{-11}$ & $6.5 \times 10^{-09}$ & $-9.8 \times 10^{-10}$ & $3.7 \times 10^{-10}$ \\
\hline Well J-13 & $2.1 \times 10^{-09}$ & $4.6 \times 10^{-09}$ & $-1.0 \times 10^{-12}$ & $-1.9 \times 10^{-12}$ & $5.1 \times 10^{-11}$ & $9.4 \times 10^{-09}$ & $4.8 \times 10^{-10}$ & $-2.5 \times 10^{-10}$ \\
\hline
\end{tabular}

\section{Industrial Wells}

Well UE-5c $\quad 1.0 \times 10^{-08} 6.7 \times 10^{-09}-9.8 \times 10^{-13}-2.7 \times 10^{-14} \quad 4.1 \times 10^{-11} 6.2 \times 10^{-09} 6.7 \times 10^{-10} 6.8 \times 10^{-11}$ Network Avg. $6.5 \times 10^{-09} 7.0 \times 10^{-09}-3.4 \times 10^{-13} 1.9 \times 10^{-11}-2.4 \times 10^{-11} 6.7 \times 10^{-09} 1.4 \times 10^{-10} 2.2 \times 10^{-10}$

\section{SEWAGE LAGOONS ( $\mu \mathrm{Ci} / \mathrm{mL})$}

\begin{tabular}{|c|c|c|c|c|}
\hline Location & Gross Beta & ${ }^{238} \mathrm{Pu}$ & ${ }^{239} \mathrm{Pu}$ & Tritium \\
\hline Area 5 RWMS Sewage Pd & $2.2 \times 10^{-08}$ & $-1.1 \times 10^{-12}$ & $9.9 \times 10^{-12}$ & $2.3 \times 10^{-08}$ \\
\hline Area 6 Yucca Sewage Pd & $1.6 \times 10^{-08}$ & $-1.6 \times 10^{-12}$ & $2.7 \times 10^{-11}$ & $1.0 \times 10^{-07}$ \\
\hline Area 6 LANL Sewage Pd & $2.9 \times 10^{-08}$ & $-1.2 \times 10^{-12}$ & $2.1 \times 10^{-10}$ & $1.4 \times 10^{-07}$ \\
\hline Area 6 DAF Sewage Pd & $1.8 \times 10^{-08}$ & $-1.0 \times 10^{-12}$ & $-3.0 \times 10^{-12}$ & $-6.4 \times 10^{-08}$ \\
\hline Area 12 Sewage Pd & $3.2 \times 10^{-09}$ & $-1.4 \times 10^{-12}$ & $-4.6 \times 10^{-12}$ & $-2.1 \times 10^{-07}$ \\
\hline Area 22 Sewage Pd & $1.6 \times 10^{-08}$ & $-1.5 \times 10^{-12}$ & $4.3 \times 10^{-11}$ & $1.9 \times 10^{-07}$ \\
\hline Area 3 Sewage Pd & $2.4 \times 10^{-08}$ & $-1.5 \times 10^{-12}$ & $7.0 \times 10^{-11}$ & $1.4 \times 10^{-07}$ \\
\hline Area 25 Central Support & $2.6 \times 10^{-08}$ & $-1.8 \times 10^{-12}$ & $5.3 \times 10^{-12}$ & $1.1 \times 10^{-07}$ \\
\hline Average & $1.9 \times 10^{-08}$ & $-1.4 \times 10^{-12}$ & $4.5 \times 10^{-11}$ & $1.7 \times 10^{-07}$ \\
\hline
\end{tabular}

\section{PONDS AND TUNNEL EFFLUENT ( $\mu \mathrm{Ci} / \mathrm{mL})$}

\begin{tabular}{|c|c|c|c|c|c|}
\hline Location & Gross Beta & Tritium & ${ }^{137} \mathrm{Cs}$ & ${ }^{238} \mathrm{Pu}$ & ${ }^{239} \mathrm{Pu}$ \\
\hline E Tunnel Effluent & $4.5 \times 10^{-08}$ & $1.1 \times 10^{-3}$ & $1.7 \times 10^{-07}$ & $4.0 \times 10^{-10}$ & $3.5 \times 10^{-09}$ \\
\hline E Tunnel Pond 2 & $8.3 \times 10^{-08}$ & $1.1 \times 10^{-3}$ & $1.5 \times 10^{-07}$ & $4.1 \times 10^{-10}$ & $3.2 \times 10^{-09}$ \\
\hline U-3cn PS\#2 Pond & -- & $1.4 \times 10^{-2}$ & --- & --- & --- \\
\hline
\end{tabular}


Table 1.7 Potable Water Sample Summary Results $(\mu \mathrm{Ci} / \mathrm{mL})$ - First Quarter, CY 1997

Location

Area 1 Building 101

Area 2 Restroom

Area 6 Cafeteria

Area 6 Building 6-900

Area 12 Building 12-23

Area 23 Mercury

Area 25 Building 4221

Average

\section{Gross Alpha}

$7.2 \times 10^{-09}$

$6.0 \times 10^{-10}$

$6.7 \times 10^{-09}$

$7.6 \times 10^{-09}$

$3.5 \times 10^{-10}$

$5.6 \times 10^{-09}$

$4.8 \times 10^{-09}$

$4.7 \times 10^{-09}$
Gross Beta

$6.5 \times 10^{-09}$

$2.9 \times 10^{-09}$

$6.7 \times 10^{-09}$

$5.2 \times 10^{-09}$

$3.2 \times 10^{-09}$

$7.4 \times 10^{-09}$

$9.2 \times 10^{-09}$

$5.9 \times 10^{-09}$
${ }^{238} \mathrm{Pu}$

$1.3 \times 10^{-12}$

$1.8 \times 10^{-12}$

$1.4 \times 10^{-12}$

$-1.1 \times 10^{-12}$

$-1.1 \times 10^{-12}$

$-1.4 \times 10^{-12}$

$-1.2 \times 10^{-12}$

$-4.6 \times 10^{-14}$
$-2.2 \times 10^{-12}$

Tritium

$-2.5 \times 10^{-12}$

$-3.5 \times 10^{-12}$

$1.8 \times 10^{-08}$

$2.4 \times 10^{-07}$

$-2.7 \times 10^{-13}$

$-2.9 \times 10^{-12}$

$-2.7 \times 10^{-12}$

$-3.5 \times 10^{-12}$

$-3.0 \times 10^{-13}$

$3.0 \times 10^{-08}$

$-1.3 \times 10^{-07}$

$-7.9 \times 10^{-08}$

$1.4 \times 10^{-07}$

$-2.4 \times 10^{-08}$

$2.8 \times 10^{-08}$

Table 1.8 Pond Water Depths in Infiltration Basins - First Quarter, CY 1997

Impound

Gate 100, Basin

Mercury, Basin

Yucca Lake

North Basin

South Basin

Tweezer.

East Basin

West Basin

CP-6

East Basin

West Basin

CP-72

DAF

Basin 1

Basin 2

Reactor Control, Basin

Test Stand 1, Basin

Test Cell C, Basin

Base Camp 25, Basin

Base Camp 12, Basin 1

Base Camp 12, Basin 2

Base Camp 12, Basin 3

Base Camp 12, Basin 4

Base Camp 12, Basin 5

RWMS-5, Basin 1

RWMS-5, Basin 2

\section{Maximum Operating}

Depth, cm

90

180

140

140

244

244

90

90

90

150

150

130

90

90

100

120

120

120

120

120

150

150
Average Depth, $\mathrm{cm}$ (First Quarter)

40

0

126

0

0

0

0

0

0

0

0

0

0

0

0

0

0

0

0

0

0

0 
Table 1.9 Influent Quality - First Quarter, CY 1997

$\begin{array}{lrc}\text { Facility } & \begin{array}{c}\text { BOD5 } \\ (\mathrm{mg} / \mathrm{L})\end{array} & \begin{array}{c}\text { S.C. } .^{(\mathrm{b})} \\ (\mu \mathrm{mh} / \mathrm{cm})\end{array} \\ \text { Gate 100 } & 257 & 2.70 \\ \text { Mercury } & 360 & 3.80 \\ \text { Yucca Lake } & 148 & 1.81 \\ \text { Tweezer } & 375 & 4.1 \\ \text { CP-6 } & 0 & 0 \\ \text { CP-72 } & 0 & 0 \\ \text { DAF } & 135 & 1.58 \\ \text { Reactor Control } & 0 & 0 \\ \text { Test Stand 1 } & 0 & 0 \\ \text { Base Camp 25 } & 192 & 1.65 \\ \text { Base Camp 12 } & 6 & 0.28 \\ \text { Test Cell C } & 0 & 0 \\ \text { RWMS-5 } & 66 & 1.35\end{array}$

(a) Biochemical Oxygen Demand

(b) Specific Conductivity

Table 1.10 Organic Loading Rates - First Quarter, CY 1997

\begin{tabular}{lcc} 
Facility & Limit (Kg/day) & Metered Rates \\
\cline { 2 - 3 } Mercury & 172 & 77.05 \\
Yucca Lake & 8.6 & 3.32 \\
Base Camp 12 & 54 & 0.04 \\
LANL on Tweezer & 5.0 & 3.52 \\
RWMS-5 & 0.955 & .32 \\
& & Calculated Rates \\
CP-6 & & $0^{(a)}$ \\
CP-72 & 8.7 & $0^{(\text {a) }}$ \\
DAF & 1.1 & 0.67 \\
Reactor Control & 7.6 & 0 \\
Eng Test Stand & 4.2 & $0^{(a)}$ \\
Test Cell C & 2.3 & $0^{(a)}$ \\
Base Camp 25 & 1.3 & 1.29 \\
Gate 100 & 7.4 & 0.54
\end{tabular}

(a) Samples not taken due to inadequate or nonexistent flow 
Table 1.11 Sample Results for Infiltration Basins that receive $30 \mathrm{~cm}$ or more of Liquid - First Quarter, CY 1997

\begin{tabular}{|c|c|c|}
\hline Parameter & $\begin{array}{l}\text { Compliance } \\
\text { Limit (mg/L) }\end{array}$ & $\begin{array}{c}\text { Measurement } \\
(\mathrm{Mg} / \mathrm{L})\end{array}$ \\
\hline
\end{tabular}

\section{AREA 6 YUCCA LAKE}

$\begin{array}{lcc}\text { Arsenic } & 0.5 & \text { (a) } \\ \text { Cadmium } & 0.1 & \text { (a) } \\ \text { Chromium } & 0.5 & \text { (a) } \\ \text { Lead } & 0.5 & \text { (a) } \\ \text { Selenium } & 0.1 & \text { (a) } \\ \text { Silver } & 0.5 & \text { (a) } \\ \text { Nitrate Nitrogen } & 100 & \text { (a) } \\ \text { Sulfate } & 5000 & 87.2 \\ \text { Chloride } & 1000 & 74.1 \\ \text { Fluoride } & 40 & 1.6 \\ \text { Tritium } & \text { (no limit) } & \text { (a) }\end{array}$

(a) None Detected

Table 1.12 Quantity of Waste Disposed of in Landfills - First Quarter, CY 1997

\begin{tabular}{lrrr} 
& \multicolumn{3}{c}{ Quantity (in pounds) } \\
\cline { 2 - 4 } Month & $\underline{\text { Area 9 }}$ & $\underline{\text { Area 23 }}$ & $\underline{\text { Area 6 }}$ \\
January & $1,870,110$ & 427,600 & 260,990 \\
February & 367,340 & 130,300 & 94,480 \\
March & $\underline{217,520}$ & $\underline{190,000}$ & $\underline{12,400}$ \\
Total & $2,454,970$ & 747,900 & 367,870 \\
\end{tabular}

Table 1.13 NEPA Documentation - First Quarter, CY 1997

Number Description

NV-93-025 Fire Training Facility, Area 23

NV-94-020 Pantex Sitewide EIS

NV-94-023 Transportation of BOMARC Missile Site Contaminated Material Area 5
File

Review

Category Status $^{(a)}$

EA Canceled

EIS $01 / 17 / 97$

EA Canceled

(a) A date in this column is the date approved. 
Table 1.13 (NEPA Documentation - First Quarter, CY 1997, cont.)

Number

Description

NV-94-026

NV-94-033

NV-95-032

NV-95-062

NV-95-066

NV-96-002

NV-97-001

NV-97-002

NV-97-003

NV-97-004

NV-97-008

NV-97-010
Liquid Waste Treatment Facility, Area 6

Storage and Disposition of Fissile Nuclear Materials, DOE

Sitewide EIS for LANL, NTS/LANL

RF Characterization Capability, Tweezer Facility, Area 11

Area 5 Low-Level Waste Management Site

Improvement Project

Cotter Concentrate Treatment Facility, Area 5

Johnson Atoll Soil Bench Scale Demonstration

Mining Training Center

Offsite Shipment of Cotter Concentrate

Recompletion of Well UE-5N

NTS Survey Control and Photo Marker Placement

Five Mobile Home Trailers at Pahute Mesa Airstrip
File

Review

Category Status $^{(a)}$

EA $\quad 01 / 14 / 97$

EIS $\quad 01 / 14 / 97$

EIS Pending

CX Pending

EA Pending

EA Withdrawn

CX 02/04/97

CX $02 / 20-97$

CX $02 / 20 / 97$

CX 02/27/97

CX Pending

CX 03/04/97

(a) A date in this column is the date approved.

Table 1.14 Environmental Occurrences at NTS Facilities - First Quarter, CY 1997

Date

Report Number

$01 / 22 / 97$
Description

Fuel Leak from August 1996 Reported

\author{
when Site Remediated \& Quantity Known
}

$\underline{\text { Status }}$

Pending 


\section{DISTRIBUTION LIST}

\section{DOE/NV}

Director, Environmental Protection Division, Nevada Operations Office, U.S. Department of Energy, Post Office Box 98518, Las Vegas, NV 89193-8518, M/S 505

N. George McNeill, Environmental Protection Division, Nevada Operations Office, U.S. Department of Energy, Post Office Box 98518, Las Vegas, NV 89193-8518, M/S 505

Technical Information Resource Center, Nevada Operations Office, U.S. Department of Energy, Post Office Box 98518, Las Vegas, NV 89193-8518, M/S 505

\section{BN}

Manager, Environmental Management Division, Bechtel Nevada, Post Office Box 98521 , Las Vegas, NV 89193-8521, M/S NLV022 (2)

Orin L. Haworth, Environmental Compliance, Bechtel Nevada, Post Office Box 98521 , Las Vegas, NV 89193-8521, M/S NTS110

Martha E. DeMarre, Coordination and Information Center, Bechtel Nevada, Post Office Box 98521, Las Vegas, NV 89193-8521, M/S NLV040

Daniel A. Gonzalez, Health Protection, Bechtel Nevada, Post Office Box 98521, Las Vegas, NV 89193-8521, M/S NTS270

\section{DSWA}

David A. Bedsun, Defense Special Weapons Agency, DOD, Post Office Box 98539 , Las Vegas, NV 89193 Las Vegas, NV 89193, M/S 573

\section{EPA}

Director, Center for Environmental Restoration, Monitoring and Emergency Response, R\&IE-LV, U.S. Environmental Protection Agency, Post Office Box 98517, Las Vegas, NV 89193-8517, M/S 513

Anita A. Mullen, Center for Environmental Restoration, Monitoring and Emergency Response, R\&IE-LV, U.S. Environmental Protection Agency, P. O. Box 98517, Las Vegas, NV 89193-8517, M/S $513(6)$

Angela Haag, Librarian, Center for Environmental Restoration, Monitoring and Emergency Response, R\&IE-LV, U.S. Environmental Protection Agency, Post Office Box 98517, Las Vegas, NV 89193-8517, M/S 513

\section{LANL}

C.F. Eberhart, M/S F670, Los Alamos National Laboratory, Post Office Box 1663, Los Alamos, NM 87545 (2) 


\section{LLNL}

Resident Manager, Lawrence Livermore National Laboratory, Post Office Box 45, Mercury, NV 89023, M/S 777

\section{SNL}

Resident Manager, Sandia National Laboratories, Post Office Box 38, Mercury, NV 89023, $\mathrm{M} / \mathrm{S} 944$

\section{State of Nevada}

Radiological Health Section, Bureau of Health Protection Services, 505 E. King Street Room 203, Carson City, NV 89710

Al Tinney, Bureau of Health Protection Services, 620 Belrose Street, Las Vegas, NV 89158-5242

Paul Liebendorfer, Nevada Division of Environmental Protection, Capitol Complex, 333 W. Nye Lane, Carson City, NV 89710

Clem Goewert, NDEP, 555 E. Washington Avenue, Suite 4300, Las Vegas, NV 89101

Clinton Case, NDEP, Capitol Complex, 333 W. Nye Lane, Carson City, NV 89710

Charles Bubak, NDEP, 555 E. Washington Avenue, Suite 4300, Las Vegas, NV 89101

Larry Franks, Radiological Health Section, NDEP, 620 Belrose Street, Las Vegas, NV 89158-5242

\section{Miscellaneous}

Office of Scientific and Technical Information, Technical Center, U.S. Department of Energy Post Office Box 62, Oak Ridge, TN 37831 (2) 
M98050562

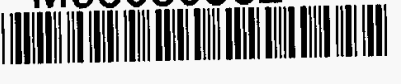

Report Number (14) DOE/NV/117/8-- 152

Publ. Date (11) $\frac{1997 / 0}{\text { SOE } / E H, X F}$
Sponsor Code (18)
UC Category (19)

DOE 